\title{
Zijn ouderen minder productief? ${ }^{1}$
}

\author{
Michiel P. de Looze, Peter R.A. Oeij, Merle M. Blok, Liesbeth Groenesteijn*
}

In de discussie over de arbeidsparticipatie van ouderen is de vraag naar de relatie tussen leeftijd en arbeidsprestatie relevant. In dit artikel wordt deze relatie beschreven aan de hand van de literatuur. Ook wordt ingegaan op de onderliggende factoren. Een denkmodel wordt geïntroduceerd waarin deze factoren zijn weergegeven in samenhang met de prestatie.

De literatuur biedt een wisselend beeld. Veel studies vinden geen verband, andere studies wijzen op een parabolisch patroon waarbij een toename in arbeidsprestatie gevolgd wordt door een afname en waarbij de ligging van de piek aanzienlijk verschilt tussen de verschillende studies

Uit het denkmodel en met name uit de prestatiebepalende factoren, namelijk de competenties en vermogens in samenhang met de functie-eisen, is de variabele relatie tussen leeftijd en prestatie te begrijpen. Daarnaast biedt het model zicht op concrete beleidsrichtingen inzake het presteren van ouderen.

Trefwoorden: leeftijd, prestatie, competenties, vermogens, functie-eisen

\section{Inleiding}

\section{Vergrijzing en arbeidsparticipatie}

Nederland vergrijst. In de beroepsbevolking zal volgens het CBS het aandeel mannen en vrouwen van 60 tot 65 jaar in 2020 respectievelijk 27 en 13 procent bedragen. In 1999 was dit nog 20 en 8 procent. Verschillen tussen bedrijfsklassen zijn groot. Energie- en waterleidingbedrijven, het onderwijs en het openbaar bestuur zijn bedrijfsklassen met veel oudere werknemers. Het aandeel 55- tot 64jarigen bedraagt circa 10-15 procent van het totaal. In de horeca, computerservice en informatietechnologie zijn veel minder ouderen actief. Het aandeel 55- tot 64-jarigen is daar minder dan vijf procent (Melser, 2004).

Door de vergrijzing verlaten grote groepen werknemers de arbeidsmarkt. De betaalbaarheid van de oudedagsvoorziening, pensioen en gezondheidszorg komt onder druk te staan. Een ander toekomstig probleem vormt het vervangingsvraagstuk, dat vanwege de vergrijzing groter zal zijn dan ooit. Ook individuele organisaties zullen gevolgen ervaren.
Wanneer veel oudere werknemers in korte tijd het bedrijf verlaten, gaan kennis en expertise verloren. Een evenwichtige leeftijdsopbouw is wenselijk voor elk bedrijf, maar wordt bedreigd door de verouderende bevolking.

Om problemen het hoofd te bieden, wordt Europees en Nederlands beleid geformuleerd om de arbeidsparticipatie van ouderen te bevorderen. Doordat de Nederlandse overheid regelingen zoals de VUT en het prepensioen lange tijd gestimuleerd heeft, is de gemiddelde arbeidsparticipatie van ouderen in Nederland relatief laag in vergelijking met het Europese gemiddelde (Peeters et al., 2005). ${ }^{2}$ De laatste jaren echter wordt in Europa en ook in Nederland bescheiden winst geboekt (Vaas \& Smulders, 1999). Positief is de toenemende bereidwilligheid van mensen om langer door te werken. De in mei 2007 verschenen nationale enquête arbeidsomstandigheden 2006, uitgevoerd door TNO, CBS en TNS NIPO, geeft aan dat ongeveer 26 procent van de werknemers wil doorwerken tot hun $65 \mathrm{e}$, terwijl dit in 2005 nog 21 procent was.

\footnotetext{
* De auteurs zijn allen verbonden aan TNO Kwaliteit van Leven in Hoofddorp. Michiel de Looze is bovendien hoogleraar aan de Faculteit Bewegingswetenschappen van de VU. Correspondentieadres: TNO, prof. dr. M.P. de Looze, Postbus 718, 2130 AS Hoofddorp. E-mail: michiel.delooze@tno.nl.
} 


\section{Beeldvorming}

Het streven naar een hogere arbeidsparticipatie wordt belemmerd door hardnekkige mythen over oudere werknemers (Nauta, De Bruin \& Cremer, 2004). Hardnekkig is het idee dat ouderen minder inzetbaar zijn. Zo denkt men dat ouderen vanwege cognitieve achteruitgang minder gemakkelijk nieuwe inzichten en vaardigheden kunnen leren (Jelicic \& Houx, 2001). Volgens Boerlijst en Van der Heijden (2003) zijn veel mensen de mening toegedaan dat ouderen langzamer van begrip en daardoor minder efficiënt zijn. Managers vinden dat promotie naar een creatieve functie voor ouderen minder vanzelfsprekend is dan voor jongeren (Simoens \& Denys, 1997). Uit onderzoek van Remery et al. bleek dat de helft van de ruim duizend ondervraagden vreest dat een verouderd personeelsbestand het nodig maakt om werkomstandigheden aan te passen aan de lichamelijke beperkingen van ouderen (Remery et al., 2001). Henkens (2005) toonde aan dat managers vinden dat medewerkers maar beter met 60 jaar kunnen uittreden als het werk fysiek zwaar is.

Er bestaan dus grote twijfels over het prestatievermogen van ouderen. Dit geldt voor alle typen functies, van kenniswerk tot fysiek zwaar werk. Bijkomende 'ideeën' over oudere werknemers betreffen de hoge loonkosten op oudere leeftijd en de verhoogde kans op ziekteverzuim (Peterson \& Coberly, 1989). Dit alles draagt er niet toe bij dat werkgevers vol enthousiasme bereid zijn oudere werknemers in dienst te nemen of te houden. Het verklaart ook de afwachtende houding van bedrijven als het gaat over de mogelijke gevolgen van de vergrijzing. ${ }^{3}$ Mede daarom domineert ook het zogenaamde ontziebeleid - ouderen in de luwte plaatsen - waar een krachtiger employabilitybeleid om de arbeidsparticipatie te ondersteunen op haar plaats zou zijn (Oeij, Korver \& Gründemann, 2003).

In hoeverre komen bovenstaande beelden overeen met de feiten?

De lonen voor verschillende leeftijdsgroepen zijn door de OECD (1998) in een groot aantal landen geïnventariseerd. Het blijkt inderdaad dat over het algemeen mensen met een hogere leeftijd (45-54 jaar) meer verdienen dan mensen in een lagere leeftijdscategorie (25-29 jaar). Na een bepaalde leeftijd zien we echter dat de stijging van de lonen met de leeftijd minder wordt en verandert in een daling. Deze daling wordt vermoedelijk veroorzaakt door de gemiddeld lagere opleiding in de onderzochte categorie van 55- tot 64-jarigen (Gelderblom, 2005).

Wat het verzuimrisico betreft, blijkt volgens het CBS dat medewerkers boven de 45 jaar minder frequent verzuimen dan medewerkers onder de 45 jaar; de verzuimduur van de 45plussers is echter gemiddeld langer, waardoor het ziekteverzuim van deze groep toch hoger is.

Opvallend echter is ook de bevinding van De Koning et al. (2003) dat de leeftijdsgroep van 55- tot 64-jarigen lager scoort qua ziekteverzuim dan de groep 45- tot 54-jarigen. Een verklaring hiervoor kan zijn dat er selectie (het zogenaamde healthy worker-effect) is opgetreden, waarbij vooral de vitale en goed presterende ouderen door blijven werken. Of zoals Nauta, De Bruijn en Cremer (2004) stellen: tegenover grote groepen ouderen die ziek of arbeidsongeschikt zijn, staan veel ouderen die tot op hoge leeftijd lichamelijk en mentaal fit zijn.

\section{Vraag}

Resteert de vraag nog naar het presteren van ouderen. Neemt het prestatievermogen met de leeftijd af of niet?

Het eerste deel van dit artikel is erop gericht aan de hand van de beschikbare studies naar leeftijd en prestatie na te gaan in hoeverre deze vraag te beantwoorden is. In hoeverre wordt de mythe van de dalende prestaties van ouderen ondersteund door de feiten, zoals bekend uit wetenschappelijk onderzoek?

Het tweede deel van dit artikel gaat in op de onderliggende factoren van de relatie van leeftijd en prestatie. Deze factoren en hun onderlinge samenhang met de prestatie worden vormgegeven in een denkmodel.

Kennis van de relatie tussen leeftijd en prestatie is van belang. Mogelijk onterechte of ongenuanceerde beeldvorming die het in dienst nemen of houden van oudere werknemers in de weg staat, kan worden ingedamd. Bovendien kan deze kennis de onderbouwing vormen voor een zinvolle discussie omtrent de loonontwikkeling met de leeftijd (zie bijvoorbeeld De Koning, Gelderblom \& Kroes, 2004). 
Kennis van de onderliggende factoren is essentieel voor het begrijpen en interpreteren van onderzoeksresultaten met betrekking tot de relatie leeftijd en presteren. Het gepresenteerde model van prestatie in samenhang met onderliggende factoren biedt in specifieke situaties (functies, bedrijven) het vereiste handvat voor de vormgeving van maatregelen ter bevordering van ouderenparticipatie.

\section{Prestaties van ouderen}

Door de jaren heen is de relatie tussen leeftijd en arbeidsprestatie of productiviteit vele malen onderwerp van studie geweest. Deze studies zijn recentelijk geïnventariseerd door Skirbekk (2003) en Gelderblom (2005), waarbij de geïnventariseerde studies elkaar ten dele overlappen. Deze reviews omvatten 23 (Skirbekk) en 24 studies (Gelderblom) die verschenen zijn in een relatief lange periode: circa 1960 tot 2004. De reviews geven een goed overzicht van de beschikbare literatuur op dit moment en geven globaal inzicht in de relatie van leeftijd en prestatie.

Wat in beide reviews naar voren komt, is het probleem met het meten van de arbeidsprestatie. In vergelijking tot het vaststellen van de lonen, is het vaststellen van de prestatie van individuele werknemers veelal complex. Grofweg worden in de gereviewde studies vier verschillende methoden gehanteerd om de individuele arbeidsprestatie te meten:

1 beoordeling van de individuele prestatie door de werknemer zelf (zelfperceptie);

2 beoordeling van de individuele prestatie door de leidinggevende;

3 analyse van de beschikbare gegevens over individuele werknemers en de werkgever ter bepaling van de individuele impact op het bedrijfsresultaat;

4 vaststelling van het aantal geleverde producten per tijdseenheid per persoon.

Elke methode om de individuele arbeidsprestatie te meten heeft zijn sterke en zwakke punten. We kunnen stellen dat methode 1 en 2 relatief eenvoudig uitvoerbaar zijn. De methoden zijn echter subjectief van aard, waarbij we ons gemakkelijk verschillende vormen van bias kunnen voorstellen. Bijvoorbeeld: een lei- dinggevende die 'meegaat in de beeldvorming dat ouderen minder kunnen presteren', een leidinggevende die ouderen juist hoger beoordeelt op basis van zijn gewaardeerde hoge staat van dienst of werknemers die van nature geneigd zijn zichzelf geen lage scores te geven. Methode 3 en vooral methode 4 zijn objectiever van aard. Bij methode 3 is het de moeilijkheid hoe de impact van een individuele werknemer geïsoleerd kan worden van andere factoren die bedrijfsresultaten beïnvloeden. Methode 4 lijkt de meest betrouwbare en objectieve methode om de individuele arbeidsprestatie te bepalen. Deze is bijvoorbeeld goed toepasbaar in productiebedrijven die discrete producten genereren. Echter, de methode wordt minder of niet toepasbaar indien producten zich minder goed laten definiëren (zoals diensten) of waarbij de individuele prestatie moeilijk te scheiden is van de teamprestatie (Gelderblom, 2005).

Naast bovengenoemde methoden wordt ook wel het loon gehanteerd als indicatie voor de arbeidsprestatie. Echter, de relatie tussen loon en prestatie ligt niet vast: De ontwikkeling van lonen met de leeftijd volgt niet per definitie de prestatiecurven van werknemers (Gelderblom, 2005). Hierdoor geeft deze methode geen betrouwbaar inzicht op de arbeidsprestatie ' $\mathrm{sec}^{\prime}$, waarin we in dit artikel geïnteresseerd zijn.

Behalve de specifieke beperkingen van de meetmethoden zijn er algemene methodische beperkingen. Een algemeen probleem is het feit dat medewerkers met lagere arbeidsprestaties eerder geneigd zullen zijn het bedrijf te verlaten. De oudere werknemers hebben daardoor waarschijnlijk een relatief hoge productiviteit (Skirbekk, 2003). Een tweede probleem treedt op wanneer jonge cohorten met oude cohorten worden vergeleken. Verschillen in arbeidsprestatie tussen de cohorten hangen daarbij niet noodzakelijkerwijs samen met het leeftijdsverschil. Veel andere factoren hebben mogelijk een veel groter effect gehad; denk aan opleidingsniveau en genoten trainingen tijdens de carrière (Gelderblom, 2005).

De door Gelderblom en Skirbekk gereviewde onderzoeken betreffen studies die zich gericht hebben op tal van verschillende sectoren. Bestudeerde beroepsgroepen zijn onder andere kantoormedewerkers, productiemedewerkers, 
onderzoekers en artiesten; andere studies hebben zich meer op de algemene beroepsbevolking gericht of hebben de onderzoekspopulatie niet nader gespecificeerd. In de reviews worden alle studies samengenomen, waardoor het trekken van conclusies bemoeilijkt kan worden. Zeker is dat beroepsgroepspecifieke effecten ondergesneeuwd raken.

Ondanks alle beperkingen komen Gelderblom en Skirbekk tot de formulering van algemene conclusies.

Skirbekk (2003) concludeert 'dat de onderzoeksbevindingen suggereren dat de individuele productiviteit uitgezet tegen de leeftijd een omgekeerd U-patroon vertoont, waarbij een toenemende arbeidsprestatie gevolgd wordt door een afname van productiviteit rond het vijftigste levensjaar'. De conclusie is vooral gebaseerd op studies waar getracht is de productiviteit min of meer objectief te bepalen, hetzij aan de hand van tellingen van producten per tijdseenheid (o.a. bij productiemedewerkers, onderzoekers, artiesten en kantoormedewerkers), hetzij aan de hand van schattingen van de impact van individuen op het bedrijfsresultaat. Studies waarin de productiviteit bepaald is aan de hand van beoordeling door de leidinggevende resulteren in het algemeen tot geen enkel verband tussen leeftijd en arbeidsprestatie.

Gelderblom (2005) ziet in de relatie tussen leeftijd en productiviteit twee patronen terugkomen. Hij spreekt ten eerste van een 'vlak patroon bij toenemende leeftijd'. Het bestaan van een dergelijk patroon wordt schijnbaar afgeleid uit die studies die geen of nauwelijks verschillen in arbeidsprestatie aantonen tussen de verschillende leeftijdsgroepen. Ten tweede onderscheidt Gelderblom een parabolisch patroon, toename op jonge leeftijd en afname op oudere leeftijd (vergelijkbaar met de omgekeerde U van Skirbekk (2003)). Gelderblom gaat in zijn review niet in op de achterliggende oorzaken van de verschillende patronen. De genoemde verschillen zouden veroorzaakt kunnen zijn door de verschillen in meetmethode. Het vlakke patroon lijkt vooral afgeleid te worden uit studies die uitgaan van de subjectieve beoordeling van leidinggevende. Beschouwen we alleen de studies in de productiesector waarbij productiviteit objectief gemeten is, dan zien we dat er in alle studies (6 in totaal) sprake is van een toename gevolgd door afname van de prestatie naarmate de leeftijd toeneemt. Waar de piek ligt, is daarbij zeer verschillend, bij sommige studies ligt de piek bij 25-34 jaar en in andere studies pas bij 50 jaar.

\section{Conclusie}

Het bestuderen van de individuele arbeidsprestatie en invloed daarop van de leeftijd wordt bemoeilijkt door tal van factoren. In een aantal studies wordt geen relatie tussen prestatie en leeftijd gevonden. Andere studies wijzen op een omgekeerd U-profiel: een toenemende arbeidsprestatie wordt gevolgd door een afname van prestaties. De afname zet zich vaak in rond het 50e levensjaar, maar uit sommige studies lijkt dit al veel eerder plaats te vinden.

$\mathrm{Nu}$ zou het interessant zijn om te weten of de nogal uiteenlopende uitkomsten van het beschikbare onderzoek samenhangen met de specifieke kenmerken van het onderzoek.

Zien we bijvoorbeeld andere patronen in een populatie van kenniswerkers in vergelijking tot een populatie van werknemers in een fysiek zwaar beroep? De afzonderlijke studies verschillen echter zo sterk, dat een betrouwbare vergelijking tussen beroepssectoren niet gemaakt wordt. Wat in dit verband wel opvallend is, is dat het omgekeerde U-profiel teruggevonden wordt in een grote verscheidenheid van beroepssectoren. Een tweede opvallende uitkomst is dat in studies waar de arbeidsprestatie min of meer objectief bepaald is, eerder een verband tussen leeftijd en prestatie wordt aangetoond dan in studies waar de arbeidsprestatie is bepaald op basis van subjectieve oordelen van leidinggevende of de werknemer zelf. De besproken beeldvorming wordt door deze conclusies ten dele bevestigd: in diverse sectoren lijkt er sprake van minder presteren door de oudere werknemers. Overigens is daarvan pas sprake na een jarenlange toename van de prestaties.

\section{Onderliggende factoren}

De literatuurstudie naar de relatie tussen leeftijd en presteren helpt ons niet veel als het gaat om het formuleren van concreet beleid ter verbetering van de arbeidsprestatie, inzetbaarheid en arbeidsparticipatie van ouderen. 
In algemene zin zijn de resultaten van de verschillende studies te wisselend. De parabolische relatie wordt niet in elke studie aangetoond, en wanneer deze wel wordt aangetoond, blijkt de ligging van de top (de piekjaren) in de studies aanzienlijk te verschillen.

In specifieke gevallen wordt de relatie duidelijker, bijvoorbeeld in de productiesector, waar de vondst van een parabolische relatie redelijk consistent is. Maar ook hier geldt dat kennis van de relatie nog niet inhoudt dat de concrete oplossingen ter verbetering van de prestaties van ouderen (indien gewenst) direct voor het oprapen liggen. Daarvoor is het nodig in te gaan op de onderliggende factoren van de prestatie en de invloed daarop van veroudering.

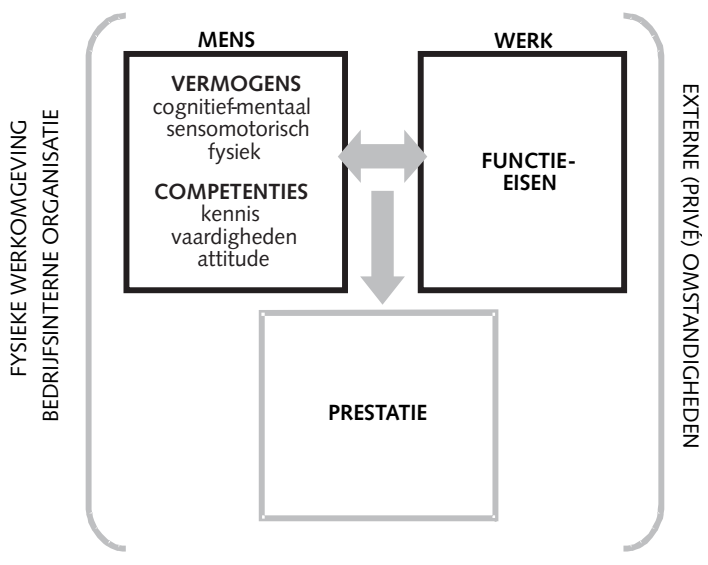

Figuur 1 De bepalende factoren van de arbeidsprestatie

In figuur 1 zijn de aan prestatie ten grondslag liggende factoren en hun invloed op de arbeidsprestatie weergegeven. Cruciaal voor de prestatie in dit model is de afstemming tussen mens en werk. Anders gezegd, indien de functie-eisen niet in balans zijn met de menselijke bronnen waaruit de werknemer kan putten, kan dit ten koste gaan van de arbeidsprestatie.

\section{Vermogens en competenties}

In een holistische mensbenadering onderscheiden we de psychobiologische vermogens en individuele competenties, waarin verschillende systemen samen onderling een geheel vormen.
De vermogens omvatten cognitief-mentale, sensomotorische en fysieke vermogens. Deze capaciteiten voeren terug tot functioneel anatomische en fysiologische parameters als hersencapaciteit, motorische coördinatie, spierkracht en uithoudingsvermogen.

Competenties verwijzen naar iemands kennis, vaardigheden en attitudes. Een competentie wordt wel gedefinieerd als 'een kenmerk van een persoon dat causaal gerelateerd is aan het niveau van presteren dat voor deze persoon haalbaar is in een specifieke context' (Spencer \& Spencer, 1993). Het zijn de competenties van een werknemer die hem in staat stellen een arbeidsprestatie te leveren. Een persoonskenmerk dat ook wordt opgevat als een competentie voor werknemers is de individuele eigenschap zich te ontwikkelen en aan te passen aan veranderende werkcondities (Ilmarinen, 2005).

Psychobiologische vermogens en competenties zijn persoonskenmerken die onlosmakelijk met elkaar zijn verbonden. Zo worden bijvoorbeeld in de veel gebruikte taxonomie van Benjamin Bloom de competenties als volgt gekoppeld aan leerdomeinen: kennis aan het cognitieve leerdomein, vaardigheden aan het psychomotorische $l=$ sensomotorische + fysieke domein in ons model) en attitudes aan het affectieve leerdomein (in ons model samenvallend met het cognitief-mentale vermogen) (Forehand, 2005).

\section{Functie-eisen}

Functie-eisen zijn de eisen die de functie stelt aan de medewerker. Hierbij gaat het niet slechts om de uit te voeren handelingen, maar ook over het omgaan met tijdsdruk, storingen, afwijkingen en onverwachte gebeurtenissen die een ingreep vereisen, een ingreep waarmee een 'regelprobleem' wordt opgelost (Vaas et al., 1995). Zulke ingrepen kunnen een gevolg zijn van diverse factoren, bijvoorbeeld het uitvallen van het computernetwerk, onjuiste of te late informatie over werkopdrachten, misverstanden tussen personen, tekort aan tijd en middelen, en onduidelijke of hoge normen. Als een taakuitvoerder niet tegemoet kan komen aan zulke situaties in het werk, stellen we vast dat het beroep dat wordt gedaan op diens persoonlijk vermogen (en daarbinnen op specifieke onderdelen) te groot is. 
Functie-eisen doen dus een beroep op de vermogens en competenties van een persoon. Tegelijkertijd verwijzen de functie-eisen ook naar de te leveren prestatie: de functie-eisen stellen wat de werkuitvoering zou moeten opleveren in kwalitatieve en kwantitatieve zin. Of dit wordt gerealiseerd, bepaalt de balans tussen functie-eisen enerzijds en vermogens en competenties anderzijds.

\section{Context}

Contextuele factoren binnen de werkorganisatie en daarbuiten beïnvloeden de menselijke vermogens en competenties, de functie-eisen, de arbeidsprestaties en de samenhang ertussen. Biedt de organisatie opleiding en training aan, dan beïnvloedt dat het kennis- en vaardigheidsniveau van de werknemers, terwijl de stijl van leidinggeven de attitude van werknemers kan beïnvloeden. Omstandigheden thuis kunnen de mentale en fysieke fitheid van de werknemer op het werk mede bepalen. Veel hangt ook af van de arbeidsverdelingstrategie. Met arbeidsverdelingstrategie verwijzen we naar de manier waarop de organisatie van de arbeid wordt vormgegeven, zoals het omgaan met eisen van flexibiliteit. Wordt flexibiliteit gerealiseerd met een grotere multi-inzetbaarheid en teamwerkachtige oplossingen, of

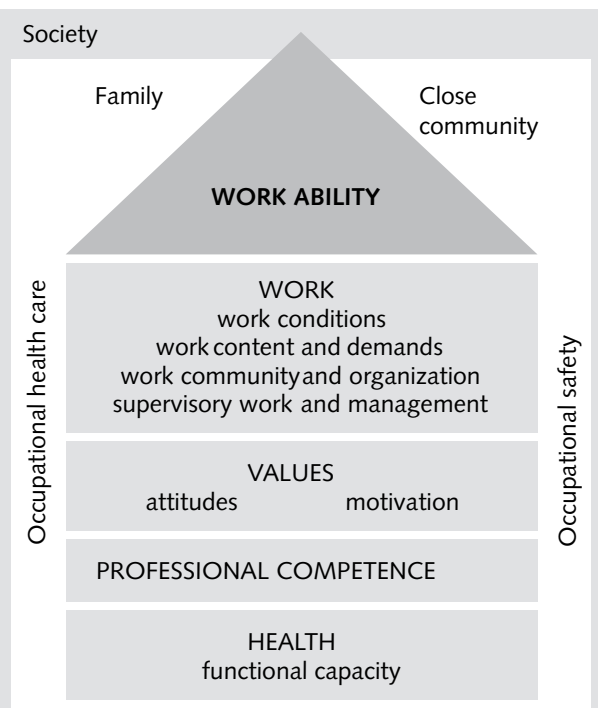

Figuur 2 Work-ability model (naar IImarinen, 2005) wordt juist meer gekozen voor uitzendwerk en flexibeler werktijden? Leiden deze keuzen tot taakverrijking (toevoegen van taken van hoger niveau), taakverbreding (toevoegen van taken van hetzelfde niveau) of taakverarming (afsplitsen van taken) en wat zijn daarvan de gevolgen voor de functie-eisen (Van Assen \& Den Hertog, 1983)? De arbeidsverdelingstrategie bepaalt mede in hoeverre een goede balans tussen vermogens/competenties en functieeisen ook daadwerkelijk resulteert in de gewenste prestaties. In de bedrijfsexterne context spelen onderwerpen als het combineren van werken en privé, druk op vergroten van de arbeidsparticipatie van ouderen, en maatschappelijk-technologische veranderingen, zoals verdergaande digitalisering.

Ons denkmodel vertoont gelijkenissen met het Finse work-ability model (figuur 2). Dit model benoemt echter niet de onderliggende factoren van de 'prestatie', maar van de 'workability', waarbij work-ability aspecten omvat van gezondheid, welzijn, inzetbaarheid en coping (Ilmarinen, 2005). Hoewel work-ability dus breder wordt opgevat, neemt de gezondheid in Ilmarinen's model wel de centrale plaats in. Gezondheid en functionele capaciteit vormen de basis van het model en gesteld wordt dat veranderingen in gezondheid en functionele capaciteiten zullen bijdragen tot een betere work-ability. Vanuit het oogpunt van de arbeidsprestatie is het vooral relevant te benadrukken dat dit sterk afhankelijk is van de taakeisen en dat gezondheidsaspecten slechts een van de factoren vormen, naast ervaringen en attitude bijvoorbeeld, die de arbeidsprestatie kunnen beïnvloeden. Ilmarinen onderkent overigens ook voor de workability (hoewel minder prominent vormgegeven) het belang van een goede balans tussen menselijke bronnen en arbeid.

Het hier geïntroduceerde model betreft een denkmodel waarin niet de kwantitatieve samenhang tussen factoren en prestatie is weergegeven. Wel biedt het model perspectief op een modelmatige benadering van de potentiële problematiek aangaande ouderen en presteren. In de volgende paragraaf wordt deze problematiek besproken aan de hand van het model en worden de uit dit denkkader voortkomende oplossingsrichtingen geformuleerd. 


\section{Veroudering en prestatie}

\section{Verouderingsprocessen}

Hoe veranderen onze vermogens en competenties met het ouder worden?

Lichamelijk wordt het allemaal wat minder. Lichamelijke vermogens zoals zien, horen, de conditie (cardiovasculair systeem, organen en locomotion) en fysieke capaciteiten (longvolume, spierkracht, flexibiliteit) nemen vooral na het 45e jaar merkbaar af. De fysiologische functies die afnemen zijn onder andere kracht, reactiesnelheid en functioneren van het zenuwstelsel; deze nemen af na ongeveer het 30 e jaar. De afname is echter maar beperkt. Pas na ongeveer het 55/60e jaar verloopt de afname sneller. Andere fysiologische veranderingen door het ouder worden zijn de achteruitgang van het evenwicht, een verminderde warmteregulatie en problemen met het herstel na het veranderen van shift (Harma, 1996). Belangrijk te vermelden is dat bovenstaande patronen gemiddelde waarden zijn en dat de interindividuele variatie in lichamelijke vermogens juist met de leeftijd toeneemt. Met andere woorden, dat een werknemer van 60 jaar een betere lichamelijke conditie heeft dan een dertig jaar jongere collega, is niet uitzonderlijk.

Er zijn verschillende aanwijzingen in de literatuur dat ook cognitieve vermogens vanaf een bepaalde leeftijd gaan afnemen. Verhagen en Salthouse (1997) analyseerden 91 studies waarin de ontwikkeling van mentale vermogens met de leeftijd werden onderzocht. Zij concludeerden dat vooral het analytische vermogen, de snelheid van denken en het werkgeheugen significant afnemen voor het 50e levensjaar en daarna sneller. Hierdoor zijn ouderen bij het oplossen van problemen minder snel, efficiënt en creatief. Deze cognitieve achteruitgang is universeel: we zien dit terug wereldwijd, bij mannen en vrouwen en bij mensen met hoge en lage cognitieve vermogens. Maar niet alle cognitieve functies gaan achteruit bij het ouder worden. De intelligentie blijft tot op hoge leeftijd op peil. Horn (1982) onderscheidt vloeiende en gekristalliseerde cognitieve vermogens. De vloeiende vermogens zijn hier de bovengenoemde (analytisch vermogen, snelheid van informatieverwerking en werkgeheugen). Hiertegenover staan de gekristalliseerde vermogens die ver- wijzen naar grotendeels automatische, op kennis gebaseerde procedurele en verbale vermogens. Deze blijken er tot het 65e jaar alleen maar op vooruit te gaan (Peeters et al., 2005). Hierdoor zouden ouderen beter scoren qua verbaal redeneren, discussiëren en begrip van grote gehelen (wijsheid).

Competenties zijn gebaseerd op kennis, ervaring en attitudes. Door een surplus aan opgebouwde kennis en ervaring zouden oudere werknemers eerder in het voordeel zijn dan jongere werknemers. De attitude (motivatie, commitment) van de oudere werknemer lijkt niet systematisch te verschillen van die van de jongere werknemer.

\section{Samenhang leeftijd en prestatie}

Met begrip van de patronen van de aan de arbeidsprestatie ten grondslag liggende factoren, kunnen we de situatieafhankelijkheid van de relatie tussen leeftijd en prestatie beter begrijpen. Tegenover de afname van lichamelijke vermogens en 'vloeiende' cognitieve vermogens op hogere leeftijd, zien we een toename in de gekristalliseerde vermogens /verbale vermogens) en een toename in opgebouwde kennis en ervaring. Wat een en ander betekent voor de arbeidsprestatie hangt af van de functie-eisen die gesteld worden (zie figuur 1).

Het technologische tijdperk waarin we ons bevinden doet vermoeden dat het vooral de cognitieve vermogens zijn, die van belang zijn. En inderdaad, voor veel beroepsgroepen zal de relatieve achteruitgang van de verschillende lichamelijke vermogens geen enkel probleem vormen. Anderzijds moeten we de hoeveelheid fysiek zwaar werk die dagelijks wordt verricht niet onderschatten. ${ }^{4}$ Met name de bouw en de zorg zijn sectoren waar de lichamelijke eisen die het werk stelt een probleem kunnen vormen voor ouderen. Voor de 'kenniswerker' is het een ander verhaal. Hier zijn de eisen cognitief van aard en is het de vraag in hoeverre er een beroep wordt gedaan op zijn vloeiende dan wel gekristalliseerde vermogens. Zijn het veelal nieuwe problemen die om een snel, efficiënt en creatief oplossend vermogen vragen, of zijn het problemen meer van terugkerende aard, die om verbale, procedurele vermogens op basis van kennis en ervaring vragen? En daarbij: zijn ouderen misschien in staat de achteruitgang 
in vloeiend vermogen te compenseren door hun gekristalliseerde vermogens?

Behalve verschillen tussen kenniswerk en fysiek zwaar werk, zien we ook verschillen tussen specialistisch en generiek werk. Nauta et al. (2005) analyseerden leeftijdsveranderingen in specialistische en generieke functies. Ruim 1.400 werknemers werden bevraagd naar hun prestatievermogen/inzetbaarheid voor hun eigen functie en voor andere functies. Het bleek dat deze met de leeftijd toenam voor de eigen functie, maar dat deze daalde voor ander functies, waarbij de inzetbaarheid significant minder daalde in de meer generieke functies. Dit voorbeeld geeft aan dat functie-eisen niet alleen een beroep doen op de persoonlijke vermogens en competenties, maar dat ze ook invloed hebben op de ontwikkeling ervan.

\section{Oplossingsrichtingen}

De vraag waarmee we dit artikel willen beëindigen luidt: hoe om te gaan met de oudere werknemer? Of beter gezegd: hoe formuleren we beleid dat tegemoetkomt aan de verschuivende, met veroudering samenhangende patronen en veranderingen en eventuele effecten op de arbeidsprestatie?

Hoe dan ook lijkt het zinvol een analyse te maken van de eisen die specifieke functies aan werknemers stellen, de specifieke vermogens en competenties van werknemers en de balans of disbalans die daarbij zou kunnen optreden. Gegeven de verscheidenheid aan functies en eisen, de verschillen in vermogens en competenties, de interindividuele variatie in verouderingsveranderingen en de verschillen in organisatorische en fysieke context, lijkt het weinig zinvol uit te gaan van generieke principes. Een analyse op maat lijkt de noodzakelijke eerste stap.

Waar dient het beleid zich vervolgens op te richten? Binnen ons model zien we grofweg drie opties: (1) het beperken van de verwachte afname van de voor de functie relevante vermogens en competenties, (2) het stimuleren van de verwachte toename van de voor de functie relevante vermogens en competenties en (3) het afstemmen van functie-eisen op de medewerker.

Het is bewezen dat trainingsprogramma's effectief zijn in het vertragen of zelfs (tijdelijk) stoppen van de cognitieve achteruitgang in snelheid van denken, redeneren en geheugen (Ball, 2002). Maar misschien moeten we oplossingen eerder zoeken binnen het werk zelf: cognitief veeleisende functies zijn juist geschikt voor ouderen omdat dat cognitieve achteruitgang voorkomt (Nauta et al., 2004). Zo'n aanpak staat haaks op een meer gangbaar beleid van het ontzien van oudere werknemers.

Een ander uitgangspunt is het stimuleren van de positieve punten. Kennis, ervaring, verbale vermogens en overzien van grote gehelen zijn positieve aspecten van de oudere werknemer. Oudere managers scoren daardoor vaak beter dan jongere managers (Colonia-Wilner, 1998). Blijf ouderen dus vooral stimuleren door het aanbod van cursussen en trainingen (ook in tegenstelling tot meer gangbaar beleid).

Het afstemmen van functie-eisen op de medewerker ten slotte is niet synoniem met het zogenaamde ontziebeleid, waarbij ouderen in de luwte worden geplaatst en jongere medewerkers de 'problematische' taken gaan overnemen. Wat betekent het wel? Allereerst kan het zinvol zijn de eisen die aan functies verbonden zijn nader te analyseren en in deze analyse taken, werkplekken, teamsamenstelling, werk- en pauzetijden te betrekken. Ervaring in de productie-industrie leert dat met slim ontwerpen en organiseren veel te bereiken valt, zowel qua productiviteit als welbevinden en gezondheid voor medewerkers (De Looze, Van Rhijn \& Tuinzaad, 2003). Dit kan voorkomen dat ouderen (en jongeren) eerder zullen afhaken. Vervolgens is het raadzaam na te gaan welke functie-eisen problemen vormen voor oudere medewerkers. De vraag is vervolgens of het 'plaatsen in de luwte' het enige alternatief vormt. Mogelijk kan met geringe ondersteuning vanuit de organisatie het werk voor de oudere weer goed uitvoerbaar worden. Bijvoorbeeld: speciale cursussen voor de omgang met informatie- en communicatietechnologie. Mogelijk kunnen we ook met geringe specifieke functieaanpassingen het werk wel hanteerbaar maken voor oudere werknemers die problemen ervaren: Te denken valt onder andere aan: de werkverdeling overdag (afwisseling licht en zwaar werk), extra pauzemogelijkheden en taakroulatie. Ook lijkt het nuttig de positieve aspecten van ouderen te beschouwen die van waarde kunnen zijn voor de organisatie en na 
te gaan of er organisatorische mogelijkheden zijn om deze in nieuw te creëren functies veel beter te benutten dan voorheen.

\section{Noten}

1 Dit artikel is opgesteld in het kader van het vraaggestuurd programma Innovatie van Arbeid (thema: Arbeidsparticipatie en Vergrijzing), waarover het ministerie van SZW de regie voert.

2 Ook een optelsom van de huidige regelingen maakt het voor ouderen nog steeds aantrekkelijk om eerder te stoppen met werken. Afschaffing van het prepensioen is onvoldoende om vervroegde uittreding te voorkomen, zo waarschuwt de Centrale Economische Commissie. (Het Financieele Dagblad, 13 maart 2007).

3 'Slechts' 55 procent van de werkgevers is zich ervan bewust dat vergrijzing een feit is en dat het daardoor noodzakelijk is geworden om oudere werknemers $(45+)$ optimaal in te zetten. De overige 45 procent van de werkgevers is het daar niet mee eens of heeft er geen mening over, zo blijkt uit onderzoek van Heliview in opdracht van Regiegroep Grijs Werkt (Het Financieele Dagblad, 21 augustus 2006).

4 Ongeveer twintig procent van de werkende bevolking verricht naar eigen zeggen (nog steeds) regelmatig zwaar werk (Andriessen, Houtman \& Hupkens, 2004).

\section{Literatuur}

Andries, F., I. Houtman \& C. Hupkens (2004). Kerncijfers arbeid. In: I.L.D. Houtman, P.G.W. Smulders en D.J. Klein Hesselink (red.). Trends in Arbeid 2004. Hoofddorp: TNO Arbeid.

Assen, A. van \& F. den Hertog (1983). Werkbeleving en werkstructurering. In: C. de Galan, M.R. van Gils \& P.J. van Strien (red.). Humanisering van de arbeid (2e dr.) (pp. 51-80). Assen: Van Gorcum.

Ball, K., D.B. Berch, K.F. Helmers, J.B. Jobe, M.D. Leveck, M. Marsiske, J.N. Morris, G.W. Rebok, D.M. Smith, S.L. Tennstedt, F.W. Unverzagt \& S.L.Willis (2002). Effects of Cognitive Training Interventions With Older Adults. 22 Journal of the American Medical Association, 288; 22712281.

Boerlijst, J.G. \& B.I.J.M. van der Heijden (2003). Leeftijdsdiversiteit in arbeidsorganisaties. In: J.J.F. Schroots (red.). Handboek psychologie van de volwassen ontwikkeling $\oplus$ veroudering. Assen: Van Gorcum.

Colonia-Willner, R. (1998). Practical Intelligence at Work: Relationship Between Aging and
Cognitive Efficiency Among Managers in a Bank Environment. Psychology and Aging, 13: 45-57.

Forehand, M. (2005). Bloom's taxonomy: Original and revised. In: M. Orey (ed.). Emerging perspectives on learning, teaching, and technology. http://www.coe.uga.edu/epltt/bloom.htm

Gelderblom, A. (2005). The relationship of age with productivity and wages. A literature review for the study Ageing and Employment. Rotterdam: SEOR, Erasmus Universiteit.

Harma, M. (1996). Ageing, physical fitness and shiftwork tolerance. Applied Ergonomics, 27: 2529.

Henkens, K. (2005). Stereotyping Older Workers and Retirement: The Managers' Point of View. Canadian Journal on Ageing, 24: 353-366.

Horn, J.L. (1982). The theory of fluid and crystallized intelligence in relation to concepts of cognitive psychology and aging in adulthood. In: S.E. Craik \& S. Trehub (eds). New directions in cognitive science. New York: Ablex.

Ilmarinen, J. (2005). Towards a longer worklife! Ageing and the quality of worklife in the European Union. Helsinki: Finnish Institute of Occupational Health/Ministry of Social Affairs and Health.

Jelicic, M. \& P.J. Houx (2001). Cognitieve veroudering: patroon determinanten en de rol van leeftijd. In: Y. Quispel \& L. Christ (red.). Ouder worden, een kwestie van leeftijd. Theorieën over leeftijd in relatie tot veroudering, levensfasen en levensloop. Utrecht: LBL.

Koning, J. de, A. Gelderblom, J. GravesteijnLigthelm \& L. van den Boom (2003). Meer vrouwen en ouderen aan het werk: Wat zijn randvoorwaarden voor werkgevers? Eindrapport. In opdracht van het Ministerie van SZW. Rotterdam: SEOR.

Koning, J. de, A. Gelderblom \& H. Kroes (2004). The wage-productivity gap for older workers, their early leave from the labour market and what can be done to prolong employment. Paper for the TLM-network, 2004.

Looze, M.P. de, M.W. van Rhijn \& B. Tuinzaad (2003). A participatory and integrative approach to improve productivity and ergonomics in assembly. Production Planning and Control, 14: 174-181.

Melser C. (2004). Welke bedrijfstakken vergrijzen? Sociaal-economische trends, 3e kwartaal, 2004, CBS.

Nauta, A., M.R. de Bruin \& R. Cremer (2004). De mythe doorbroken. Gezondheid en inzetbaarheid oudere werknemers. Hoofddorp: TNO Arbeid.

Nauta, A., E. de Vroome, E. Cox, T. Korver \& K. Kraan (2004). De invloed van functietype op het verband tussen leeftijd en inzetbaarheid. Gedrag 4) Organisatie, 18: 326-336.

OECD (1998). Work force ageing in OECD countries 107, 285-326. 
Oeij, P., T. Korver \& R. Gründemann (2003). Arbeidsmarkt en oudere werknemers. In: I.L.D. Houtman, P.G.W. Smulders \& D.J. Klein Hesselink (red.). Trends in arbeid 2004 (pp. 145169). Hoofddorp: TNO Arbeid.

Peeters, M.C.W., A. Nauta, J. Jonge \& R. Schalk (2005). The future of older employees: the revival of an 'old' theme in Work and Organizational Psychology, Gedrag «) Organisatie, 18: 297-308.

Peterson, D. \& S. Coberly (1989). The Older Worker: Myths and Realities. In: R. Morris \& S.A. Bass. Retirement Reconsidered: Economic and Social Roles for Older People. New York: Springer, pp. 116-128.

Remery, Ch., R. Henkens, J. Schippers \& P. Ekamper (2003). Managing an ageing workforce and a tight labour market: views held by Dutch employers. Research and Policy Review, 22: 21-44.

Simoens, P. \& J. Denys (1997). Wie werkt nog na vifftig? Leuven: HIVA-series no. 17.

Skirbekk, V. (2003). Age and individual productivity: A literature survey. MPIDR Working Paper
WP 2003-028. Rostock: Max-Planck-Institut für demografische Forschung (mimeo).

Sluiter, J.K. (2006). High demand jobs: Age-related diversity in work ability. Applied Ergonomics, 37 (4): 429-440.

Spencer, L. \& S. Spencer (1993). Competence at work: Models for superior performance. New York: Wiley and Sons.

Vaas, F. \& P. Smulders (1999). Arbeidsparticipatie van ouderen. In; I.L.D. Houtman, P.G.W. Smulders \& D.J. Klein Hesselink (red.). Trends in arbeid 1999 (pp. 237-262). Alphen aan den Rijn: TNO Arbeid/Samsom.

Vaas, S., S. Dhondt, M.H.H. Peeters \& J. Middendorp (1995). De WEBA-methode: Deel 1 WEBA-analyse handleiding. Alphen aan den Rijn/Zaventem: Samsom BedrijfsInformatie.

Verhaegen, P. \& T.A. Salthouse (1997). MetaAnalyses of Age-Cognition Relations in Adulthood. Estimates of Linear and Nonlinear Age Effects and Structural Models. Psychological Bulletin, 122: 231-249. 